ISSN:

Print - 2277-078X

Online - $2315-747 \mathrm{X}$

(c) UNAAB 2019

\title{
EFFECTS OF EXCHANGE RATE MOVEMENTS ON EXPORT OF SOME SELECTED AGRICULTURAL PRODUCTS IN EMERGING AFRICAN COUNTRIES
}

\author{
${ }^{*}$ E. A. OLUBIYI, 2F. KOLADE AND ${ }^{2}$ D. A. DAIRO \\ 1D epartment of Economics, College of Management Science, Federal University of \\ Agriculture Abeokuta \\ 2D epartment of Agricultural Economics, Federal University of Agriculture Abeokuta \\ *Corresponding Author. \\ Tel:
}

\begin{abstract}
ABST RACTS
This study investigates the effect of exchange rate movement on export of five selected agricultural products, in five emerging countries in Africa. Autoregressive Distributed Lag (ARDL) method was employed to analyse the data spanning 1995 to 2015. It was found that, in the short run, exchange rate has a mixed effect on the product across countries, that is, in some products and countries, exchange rate affects export positively, while in some countries and product exchange rate movement has a negative effect on export. Further, exchange rate does not have long run effect on sugar and fruits and nuts in most of the countries. Consequently, it is recommended that government, in countries where exchange rate depreciation increases export, should maintain depreciation. Further, there should be provision of adequate infrastructure that will enhance agricultural production. In the same vein, interest rate on loans given to farmers should be minimal, so as to encourage borrowing to finance agricultural production. This recommendation is mostly relevant to countries where interest rate affects export negatively.
\end{abstract}

Keywords: Exchange rate, agriculture exports, Autoregressive Distributed Lag

\section{INTRODUCTION}

Agriculture has been an integral sector for almost all the economies in the world. This sector is so important that it not only generate employment; but also serve as source of export earnings to most developing economies (Aktas et al, 2015). In the African region, most of the countries are major world producers of some agriculture products (World Bank, 2019). The statistics from the Food and Agriculture Organization of United Nations (FAOSTAT, 2018) reports that some emerging countries like G hana, Egypt, Nigeria, Kenya and South Africa (hereinafter referred to as the GENKSA countries) are major producers of some agriculture products. Specifically, statistics has indicated that Ghana and Nigeria are endowed with cocoa, South Africa and Egypt are endowed with fruits and nuts, Egypt, Kenya and South Africa are endowed with vegetables, South Africa and Egypt are endowed with sugar, and Kenya endowed with coffee and tea (FAOSTAT, 2018. The exports of some agriculture products have also contributed to foreign exchange earnings of these countries. For instance, Kenya's tea and coffee exports generate average of $70 \%$ 
of foreign exchange earnings (Economic Survey, 2005). Aside oil, agriculture products are the second source of foreign exchange earnings from economic activity for Nigeria, G hana South Africa and Egypt (Economic Survey, 2005). Besides, agriculture sector is key to employment creation and source of wealth for the GENKSA populace (Ali, 2017).

However, the foreign exchange earned from the export of these agricultural products is influenced by different factors which include exchange rate movement, government policies, and domestic consumption among others (Adekunle and Udukwe, 2018). Of all these factors, exchange rate dynamics appears to play the most crucial role (D incer and Kandil, 2011). This is true because exchange rate changes place uncertainty on the value of exports, thereby, affecting decision to produce and export. For instance, during depreciation, the value of exports denominated in domestic currency will increase. But whether this will translate to more profit or not depends on the source of factor input on one hand and the exchange rate elasticity of export on the other hand. If the bulk of input employed in the production of these products is imported, then depreciation will also increase cost of production and hence reduce profit. If the exchange rate elasticity of export is inelastic, then large depreciation will only be followed with mild increase in demand and hence small export earnings denominated in domestic currency (Levi, 2014).

Most African countries, particularly the emerging markets in the region, have operated different exchange rate regimes such as fixed exchange rate regime, flexible exchange rate regime and presently, different types of exchange rates still prevail in these countries. While South Africa is known for operating partial floating exchange rate, $\mathrm{Ni}$ geria is practicing managed floating exchange rate with allowance for exchange rate windows such as Bureau de Change and parallel market exchange rate (CBN, 2019). One attribute of the variants of floating exchange rate or the allowance for foreign exchange transaction window sis practiced is that the direction of movement is not perfectly predictable and this increases the risk of engaging in international activity (Genc, and Kibritci, 2014).

According to Junwook (2016), movement in exchange rate tends to influence exporters' decision on whether to export or sell in the domestic markets. In the case of agriculture sector, risk averse farmers may be discouraged to export if the exchange rate movement is frequent and persists because export revenue, which determine the profit of the farmers are not certain (Ali, 2017). The implication of this is that export will fall, agriculture activity will dwindle with consequent effect of low foreign exchange earnings, rising unemployment rate and low standard of living. For the risk lover farmers, persistent exchange rate movement could motivate increase in production and export, but they tend to hedge out risk by stocking the produce or by engaging in forward exchange rate (Junwook, 2016). Meanwhile, the risk averse agriculture exporters can also take advantage of exchange rate movement if it will increase expected margin of utility of the revenue realized from agriculture exports thereby motivating farmers to export.

The above analysis is yet to be tested for some agriculture exports for which the emerging economies of Africa have highest comparative advantage. The emerging economies of Africa are of interest due to their 
EFFECTS OF EXCHANGE RATE MOVEMENTS ON EXPORT OF SOME...

economic position in the region. First, these economies have been identified as the major economic hub of Africa (IMF, 2018). Second, they* also account for more than 30 percent of total agriculture export of the region. Third, the authorities in these economies have embarked on various policies to encourage agriculture exports but also exhibit most prevalent exchange rate movement. Hence, it is important to examine how the movement in exchange rate has fared well in the export of some agriculture products. Selected agriculture products for this study are cocoa, fruits and nuts, vegetable, coffee, and sugar which are the five major agriculture products exported by these countries.

*These countries were Ghana, , Egypt, Nigeria, South Africa, and Kenya but recently included are Bostwana, Mozambique, Tanzania, Uganda and Zambia (IMF, 2018)

\section{BRIE F REVIEW OF LITERATURE}

Research works on the effects of exchange rate movement on product exports is large and still increasing. Hence, this study focuses on the recent empirical evidence on the effects of exchange rate movement on exports of agriculture products. Hasanov and Samadova (2010) analyze how real exchange rate affect non-oil export using Azerbaijan as a case study, the study suggests based on the estimation result that the effect exchange rate has on export in the non-oil export is negative. The study reveals that appreciation in exchange rate is one of the major factors that contributed to fall of the non-oil sector in Azerbaijan.

Saeid and Sleelavat (2013) investigates the relationship between exchange rate and agriculture exports in India in the period 1980
-2010, The result indicates that there is no significant relationship between exchange rate and export. The least square regression analysis also show a sign of positive effect of exchange rate changes on agriculture exports but the coefficient is not significant. Further, there is no long run relationship among the variables since the test of the cointegration rejects possible long run relationship

Genc and Kibritci (2014) seek to unravel the pattern of relationship between trade (export and imports) and exchange rate of selected emerging countries. The authors apply panel co-integration method for data spanning 1985-2012 for 22 countries. The error correction coefficient was negative and significant, suggesting that there is a long run relationship between exports and exchange rate changes. The speed of convergence to the long run is slow, posting $25 \%$ of recovery in the contemporaneous year. However, the result suggests that exchange rate has no significant effect on export in the long run. In the short run, the effect is significant and notable.

Hsu, \&al (2014) are interested in how exchange rate changes affect export structure of Chinese and focusing particularly on the effect of sudden appreciation in Chinese remmimbi in June 2005. D ata were collected on firm-product-destination-month level spanning 2000 to 2006 on HS 8-digit product classification. The authors utilize difference-indifference regression method to show that the structure of Chinese export respond to exchange rate just as it happens in the developed countries. In this case, appreciation increases exports while depreciation reduces exports.

Aktas \&al. (2015) employ Turkish monthly 
export and exchange rate data between 2002 and 2013 to analyse the short and long run effect of exchange rate on the exports of agricultural products. The authors compute exchange rate uncertainty by utilizing exponential generalized autoregressive conditional heteroskedasticity (EGARCH) method. After the validity of the existence of possible long run (albeit, weak) relationship, the study finds long run positive and significant effect of exchange rate uncertainty (volatility) on export of agricultural exports in Turkey. O wing to the weak long run relationship, the speed of convergence is remote. However, the result suggests that depreciation is export enhancing for agricultural products of Turkey.

Malik \& al. (2016) carry out an empirical investigation on how exports of Pakistan are affected by exchange rate movement. The result of the structured least square regression equations suggest that exchange rate have negative and significant effect on export between 1981-2010. O binwata $\&$ al. (2016) examine the export impact of exchange rate volatility between 1970 and 2015 in Nigeria. Utilizing a time series data in the period, it was found that even amidst policy pronouncement, exchange rate volatility is one of the important factors that determine export in Nigeria. The effect of exchange rate on firm-level export in China was carried out by Li, $\notin$ al. (2015) within the period of 2000-2007. The study reveals that prices of exports on Chinese exchange rate is very small, pointing to the fact that relative high exchange rate pass through into foreign currencies dominated prices while the volume response is moderate and significant. Wondemu and Potis (2016) carried out an assessment of the export effects of real exchange rate in Ethiopia and Tanzania. They found that exports respond significantly to exchange rate changes in both countries. In particular, exports value increases when real exchange rate depreciates while in decreases when exchange rate appreciates.

The study of firm level analysis of the effect of agricultural exports in Pakistan was carried out by Ali (2017). The firm level analysis covers the period of 2000-2013. The author conducts firm-level agriculture trade flows by utilizing the foreign value of export invoicing denominated in domestic currency using the exchange rate to do the conversion. The result of the exercise reveals that exchange rate movement positively and significantly influences agriculture exports at both the intensive and extensive margin. Specifically, Pakistani exchange rate depreciation tends to increase the extensive margin of firm exports. Adekunle and Innocent (2018) examine possible asymmetric effect of real exchange rate on agriculture output performance in Nigeria between 1981 and 2016. The study finds significant role of exchange rate effect on agriculture products, however, the shock to volatility is not asymmetric. In the short run, exchange rate depreciation enhances agriculture export.

From the review, it is clear that the effect of exchange rate on export products is not clear. However, little is known about how exchange rate affects agriculture export at the product level and across countries. This is a big gap in the literature because policy makers may be misdirected by assuming that all agriculture products are affected by exchange rate in the same way whereas it is not. This is the gap that this study fills.

\section{MATE RIALS AND METHODS OF RESEARCH}

The underlying theory employed for this work is the Marshall (1923) and Lerner 
(1944) elasticity approach on the effect on exports of exchange rate. The theory provides a condition under which exchange rate devaluation could lead to increase in export earnings so that the balance of trade is favorable. In this regard, a country is said to have a favorable balance of trade when the country's export is greater than import. According to the theory, devaluation of domestic currency will be export enhancing if the degree of responsiveness of export to devaluation is higher than the degree of responsiveness of imports to devaluation. Specifically, the condition for balance of trade improvement is that the sum of the exchange rate elasticity of exports and imports must be greater than unity. Follow- ing the analysis of the theory, the appropriate model specification in shown in equation 1 :

$$
X_{t}=g\left(\operatorname{ext}_{t}, V\right)
$$

Where $X_{t}$ is agriculture export product and $e x t_{t}$ is nominal effective exchange rate and $\mathrm{V}$ represent other variables that affect export of agriculture products. Possible variables considered are availability of arable land, inflation rate, interest rate, and agriculture export tax. Expressing the above equation in logarithmic form and taking into consideration all the control variables, the ARDL form for each agriculture export product is presented in equations 2 to 6 :

\section{RDL model for export of COCOA}

$$
\begin{aligned}
& \Delta \ln X P C O C O A_{t-j}=\delta+\sum_{t-1}^{\rho} \delta_{1} \Delta \ln X P C O C O A_{t-1}+\sum_{t-0}^{q} \delta_{2} \Delta \ln E X C_{t-1}+\sum_{t=0}^{r} \delta_{3} \Delta \ln I N F_{t-1}+\sum_{t-0}^{s} \delta_{4} \Delta \ln R T_{t-1} \\
& +\sum_{t=0}^{t} \delta_{5} \Delta \ln T R_{t-1}+\sum_{t-0}^{e} \delta_{6} \Delta \ln T R A C T_{t-1}+\beta_{1} \ln X P_{t-1}+ \\
& \beta_{2} \ln E X C_{t-1}+\beta_{3} \ln I N F_{t-1}+\beta_{4} \ln R T_{t-1}+\beta_{5} \ln T R_{t-1}+\beta_{1} \ln T R A C T_{t-1}+N_{t}(2)
\end{aligned}
$$

\section{ARDL model for export of COFFEE}

$$
\begin{aligned}
& \triangle \ln X P C O F F E E_{t-j}=\delta+\sum_{t=1}^{\rho} \delta_{1} \Delta \ln X P C O F F E E_{t-1}+\sum_{t=0}^{q} \delta_{2} \Delta \ln E X C_{t-1}+\sum_{t-0}^{r} \delta_{3} \Delta \ln I N F_{t-1}+\sum_{t-0}^{s} \delta_{4} \Delta \ln R T_{t-1} \\
& +\sum_{t=0}^{t} \delta_{5} \Delta \ln T R_{t-1}+\sum_{t-0}^{U} \delta_{6} \Delta \ln T R A C T_{t-1}+\beta_{1} \ln X P_{t-1}+ \\
& \beta_{2} \ln E X C_{t-1}+\beta_{3} \ln I N F_{t-1}+\beta_{4} \ln R T_{t-1}+\beta_{5} \ln T R_{t-1}+\beta_{1} \ln T R A C T_{t-1}+\kappa_{t}
\end{aligned}
$$

\section{ARDL model for export of SUGAR}

$$
\begin{aligned}
& \Delta \operatorname{lnXPSUGAR_{t-j}}=\delta+\sum_{t-1}^{e} \delta_{1} \Delta \ln X \text { PSUGAR }_{t-1}+\sum_{t-0}^{q} \delta_{2} \Delta \ln E X C_{t-1}+\sum_{t-0}^{r} \delta_{3} \Delta \ln I N F_{t-1}+\sum_{t-0}^{s} \delta_{4} \Delta \ln R T_{t-1} \\
& +\sum_{t=0}^{t} \delta_{5} \Delta \ln T R_{t-1}+\sum_{t=0}^{U} \delta_{6} \Delta \ln T R A C T_{t-1}+\beta_{1} \ln X P_{t-1}+ \\
& \beta_{2} \ln E X C_{t-1}+\beta_{3} \ln I N F_{t-1}+\beta_{4} \ln R T_{t-1}+\beta_{5} \ln T R_{t-1}+\beta_{1} \ln T R A C T_{t-1}+\aleph_{t}
\end{aligned}
$$




$$
\begin{aligned}
& \text { ARDL model for export of VE GETABLES } \\
& \triangle \ln X P V E G E T A B L E S_{t-j}=\delta+\sum_{t-1}^{\rho} \delta_{1} \Delta \ln X P V E G E T A B L E S_{t-1}+\sum_{t-0}^{q} \delta_{2} \Delta \ln E X C_{t-1}+\sum_{t=0}^{r} \delta_{3} \Delta \ln I N F_{t-1}+\sum_{t=0}^{s} \delta_{4} \Delta \ln R T_{t-1} \\
& +\sum_{t=0}^{t} \delta_{s} \Delta \ln T R_{t-1}+\sum_{t=0}^{U} \delta_{6} \Delta \ln T R A C T_{t-1}+\beta_{1} \ln X P_{t-1}+ \\
& \beta_{2} \ln E X C_{t-1}+\beta_{3} \ln I N F_{t-1}+\beta_{4} \ln R T_{t-1}+\beta_{5} \ln T R_{t-1}+\beta_{1} \ln T R A C T_{t-1}+\aleph_{t}
\end{aligned}
$$

\section{ARDL model for export of FRUITS AN D N UTS}

$$
\begin{aligned}
& \triangle \operatorname{lnXPFRUITS} \& \text { NUTS } S_{t-j}=\delta+\sum_{t-1}^{p} \delta_{1} \Delta \ln X P F R U I T S \& N U T S_{t-1}+\sum_{t-0}^{q} \delta_{2} \Delta l n E X C_{t-1}+\sum_{t=0}^{r} \delta_{3} I N F_{t-1}+\sum_{t=0}^{s} \delta_{4} \Delta R T_{t-1} \\
& +\sum_{t=0}^{t} \delta_{5} \Delta \ln T R_{t-1}+\sum_{t-0}^{U} \delta_{6} \Delta \ln T R A C T_{t-1}+\beta_{1} \ln X P_{t-1}+ \\
& \beta_{2} \ln E X C_{t-1}+\beta_{3} \ln I N F_{t-1}+\beta_{4} \ln R T_{t-1}+\beta_{5} \ln T R_{t-1}+\beta_{1} \ln T R A C T_{t-1}+\kappa_{t}
\end{aligned}
$$

where $\ln \mathrm{X}_{\text {it-j }}$ is natural $\log$ of lag of export for time tin country ; $\operatorname{lnEXC}$ is the natural log of exchange rate at time tin country $i$, INF is inflation rate at time tin country $i$, $\mathrm{RT}$ is interest rate at time tin country $\mathrm{i}$, $\operatorname{lnTR}$ is the natural log of tax on export at time tin country $\mathrm{i}$, InTRACT is the natural log of the size of agriculture equipment, proxy by numbers of tractors at time tin country i, $\Delta$ denotes the first difference operator, $\delta$ denote the drift component, $\eta_{t}$ is white noise, $\delta^{\prime} s$ is the coefficient of the short run dynamics and $\beta$ 's is the long run coefficients.

The ARD L refers to a mathematical expression in which the dependent variable is partially explained by its lagged values, the current and past lags of the explanatory variables (Pesaran and Shin, 1995). The ARDL approach is useful in determining the co- integrating vectors, that is, each of the variables represents a single long run relationship in the model. The ARDL can differentiate the dependent variable from the independent variable when there is a single long run relationship Perasan and Shin, 1995). The ARDL approach assumes that between the dependent variable and the independent variable there exist only one form of equation relationship. The ARDL bound test is used for testing the long run relationship of variables (Pesaran and Shin, 1995; Pesaran \&al, 1996b). The ARDL co-integration test is useful in determining if the underlying variables co-integrate or if they do not cointegrate. This approach is considered appropriate for this work because of the nature data and the objectives of the study.

\section{RESULTS AND DISCUSSIONS}


EFFECTS OF EXCHANGE RATE MOVEMENTS ON EXPORT OF SOME...

\begin{tabular}{|c|c|c|c|c|c|c|c|c|}
\hline \multirow{2}{*}{$\begin{array}{l}\text { COUN- } \\
\text { TRIES }\end{array}$} & \multicolumn{4}{|c|}{ LEVEL } & \multicolumn{3}{|c|}{ FIRST DIFFERENCING } & \multirow{2}{*}{$\begin{array}{c}\text { RE- } \\
\text { MARK } \\
\text { I(d) }\end{array}$} \\
\hline & $\begin{array}{l}\text { VARIA- } \\
\text { BLES }\end{array}$ & $\begin{array}{c}\text { MODEL } \\
1 \\
\end{array}$ & $\begin{array}{c}\text { MOD- } \\
\text { EL } 2 \\
\end{array}$ & $\begin{array}{c}\text { MOD- } \\
\text { EL } 3\end{array}$ & MODEL 1 & MODEL 2 & MODEL 3 & \\
\hline \multirow[b]{3}{*}{$\begin{array}{l}\text { SO UTH } \\
\text { AFRICA }\end{array}$} & $\begin{array}{l}\text { EXC } \\
\text { INF }\end{array}$ & $\begin{array}{c}1.745 \\
-1.001\end{array}$ & $\begin{array}{l}-1.45 \\
-3.278\end{array}$ & $\begin{array}{l}-2.52 \\
-4.22\end{array}$ & $\begin{array}{l}-2.704^{* * *} \\
-7.269 *\end{array}$ & $\begin{array}{l}-2.948^{* *} \\
-7.210^{*}\end{array}$ & $\begin{array}{l}-2.803^{* *} \\
-7.006^{*}\end{array}$ & $\begin{array}{l}\mathrm{T}(1) \\
\mathrm{I}(1)\end{array}$ \\
\hline & TRAC & $-9.662^{*}$ & $-3.314^{* *}$ & $-4.945^{*}$ & $\ldots \ldots \ldots$ & ......... & $\ldots \ldots \ldots \ldots$ & $\mathrm{I}(0)$ \\
\hline & $\begin{array}{c}\text { TR } \\
\text { RT } \\
\text { XPF\&N } \\
\text { XPVEG } \\
\text { XPSUG } \\
\text { XPCOA } \\
\text { XPCOF }\end{array}$ & $\begin{array}{c}-0.483 \\
-3.512 \\
1.775 \\
0.789 \\
-0.167 \\
-0.432 \\
0.168\end{array}$ & $\begin{array}{r}-2.159 \\
-2.002 \\
0.011 \\
-0.779 \\
-2.701 \\
-1.993 \\
-0.912\end{array}$ & $\begin{array}{l}-3.25 \\
-2.67 \\
-2.62 \\
-2.22 \\
-3.35 \\
-1.94 \\
1.503\end{array}$ & $\begin{array}{c}-4.306^{*} \\
-6.028^{*} \\
-3.06^{* * *} \\
-4.501 * \\
-3.969^{*} \\
-5.180^{* * *} \\
-3.194^{*}\end{array}$ & $\begin{array}{c}-4.252^{*} \\
-6.027 * \\
3.332^{* *} \\
-4.552 * \\
-3.722^{* *} \\
-5.062^{* * *} \\
-3.100^{* * *}\end{array}$ & $\begin{array}{c}-4.245^{* *} \\
-6.078^{*} \\
-3.366^{*} \\
-4.483^{*} \\
-3.373^{*} \\
-5.081^{* * *} \\
-3.155^{*}\end{array}$ & $\begin{array}{l}\mathrm{I}(1) \\
\mathrm{I}(1) \\
\mathrm{I}(1) \\
\mathrm{I}(1) \\
\mathrm{I}(1) \\
\mathrm{I}(1) \\
\mathrm{I}(1)\end{array}$ \\
\hline \multirow{7}{*}{$\begin{array}{l}\text { NIGE- } \\
\text { RIA }\end{array}$} & EXC & 1.187 & -1.874 & -1.76 & $-3.914 * *$ & $-4.282^{* * *}$ & $-4.511 * *$ & I(1) \\
\hline & $\begin{array}{l}\text { INF } \\
\text { TRAC }\end{array}$ & $\begin{array}{c}-4.829 \\
-2.252^{* * *}\end{array}$ & $\begin{array}{c}-5.924 \\
-2.184^{* *}\end{array}$ & $\begin{array}{c}-5.64 \\
-0.615^{* * *}\end{array}$ & $-3.547 * * *$ & $-4.180^{* * * *}$ & $-5.199 * * *$ & $\begin{array}{l}\mathrm{I}(1) \\
\mathrm{I}(0)\end{array}$ \\
\hline & $\begin{array}{l}\text { TR } \\
\text { RT }\end{array}$ & $\begin{array}{c}0.111 \\
-5.393^{* * *}\end{array}$ & $\begin{array}{c}-1.293 \\
-5.751 * * *\end{array}$ & $\begin{array}{c}-4.84 \\
-5.518^{* * *}\end{array}$ & $-3.227802^{* * *}$ & $-3.198^{* *}$ & $-3.145^{* * *}$ & $\begin{array}{l}\mathrm{I}(1) \\
\mathrm{I}(0)\end{array}$ \\
\hline & $\begin{array}{l}\text { XPF\&N } \\
\text { XPYF G }\end{array}$ & $\begin{array}{l}0.879 \\
0779\end{array}$ & -0.404 & -1.76 & $\begin{array}{l}-3.613^{*} \\
250061 * * *\end{array}$ & $-3.796 * * *$ & $-3.540^{*}$ & $\mathrm{I}(1)$ \\
\hline & $\begin{array}{l}\text { XPVE G } \\
\text { XPSUG }\end{array}$ & $\begin{array}{l}0.779 \\
0.348\end{array}$ & $\begin{array}{l}-0.816 \\
-0.966\end{array}$ & $\begin{array}{l}-2.14 \\
-3.97\end{array}$ & $\begin{array}{l}-3.599641 * * * \\
-4.907 * * *\end{array}$ & $\begin{array}{l}-3.814654 * * * \\
-5.041 * * *\end{array}$ & $\begin{array}{l}-2.768060 * * \\
-4.729 * * *\end{array}$ & $\begin{array}{l}\mathrm{I}(1) \\
\mathrm{I}(1)\end{array}$ \\
\hline & XPCOA & 1.011 & -1.167 & -2.76 & $-6.251^{* * *}$ & $-6.358^{* * *}$ & $-6.185^{* * *}$ & $\mathrm{I}(1)$ \\
\hline & XPCOF & -0.729 & -3.76 & -3.7 & $-5.524^{* * *}$ & $-5.420 * * *$ & $-5.490^{* * *}$ & I(1) \\
\hline \multirow{9}{*}{ EGYPT } & EXC & 2.321 & -0.885 & -2.45 & $-2.167 * *$ & $-2.657 * * *$ & $-2.578 * *$ & I(1) \\
\hline & INF & $-1.752^{*}$ & $-4.140^{* * *}$ & $-4.191 * * *$ & & & & $\mathrm{I}(0)$ \\
\hline & TRAC & 1.940 & -0.509 & -1.43 & $-2.712^{* *}$ & $-3.156^{* *}$ & $-2.423^{* *}$ & I(1) \\
\hline & TR & -1.46 & -1.316 & -4.42 & $-3.966^{* * *}$ & $-4.289 * * *$ & $-4.345^{* *}$ & I(1) \\
\hline & RT & -3.5 & 1.88 & $-1,526$ & $-1.751 *$ & $-6.394 * * *$ & $-4.655 * *$ & I(1) \\
\hline & $\begin{array}{l}\text { XPF\&N } \\
\text { XPYFG }\end{array}$ & $\begin{array}{l}2.241 \\
2.053\end{array}$ & $\begin{array}{r}-0.523 \\
0.309\end{array}$ & -2.44 & $-4.478 * *$ & $-5.992 * * *$ & $-5.810^{* * *}$ & I(1) \\
\hline & $\begin{array}{l}\text { APVEG } \\
\text { XPSUG }\end{array}$ & $\begin{array}{r}2.053 \\
-2.456\end{array}$ & $\begin{array}{l}0.309 \\
-0.9\end{array}$ & $\begin{array}{l}-3.37 \\
-2.69\end{array}$ & $\begin{array}{l}-2.988^{* * *} \\
-4.114^{* * *}\end{array}$ & $\begin{array}{l}-3.729 * * \\
-4.583 * * *\end{array}$ & $\begin{array}{l}-3.451^{* *} \\
-4.418^{* *}\end{array}$ & $\begin{array}{l}\mathrm{I}(1) \\
\mathrm{I}(1)\end{array}$ \\
\hline & XPCOA & 2.62638 & 0.096 & -5.14 & $-7.072 * * *$ & $-8.894 * * *$ & $-8.467 * * *$ & I(1) \\
\hline & XPCOF & 1.243 & -1.256 & -0.9 & $-4.512 * * *$ & $-4.878^{* * *}$ & $-5.019 * * *$ & I(1) \\
\hline \multirow{10}{*}{$\begin{array}{l}\text { GHA- } \\
\text { NA }\end{array}$} & EXC & -1.281 & -1.87 & -2.84 & $-2.306^{* *}$ & $-3.351^{* *}$ & $-3.349 *$ & I(1) \\
\hline & INF & $-2.098 * *$ & $-4.384^{* *}$ & $-4.498^{* * * *}$ & & & & $\mathrm{I}(0)$ \\
\hline & TRAC & -0.586 & -2.193 & -2.22 & $-5.626 * * *$ & $-0.942 * *$ & $-1.355^{* *}$ & I(1) \\
\hline & TR & -0.206 & -2.402 & -3.04 & $-5.352^{* * *}$ & $-5.373^{* * *}$ & $-4.657 * * *$ & I(1) \\
\hline & RT & -1.259 & -1.352 & -1.74 & $-4.296 * * *$ & $-4.798^{* * *}$ & $-5.454^{* * *}$ & I(1) \\
\hline & XPF\&N & 2.099 & -1.35 & -2.89 & $-5.597 * * *$ & $-6.599 * * *$ & $-6.739 * * *$ & I(1) \\
\hline & XPVEG & 0.597 & -1.236 & -1.29 & $-1.504^{* *}$ & $-1.585^{* *}$ & $-1.812^{*}$ & I(1) \\
\hline & XPSUG & -0.252 & -4.47 & -4.34 & $-5.522^{* * *}$ & $-5.351^{* * *}$ & $-4.728^{* * * *}$ & I(1) \\
\hline & XPCOA & 1.342 & -0.865 & -0.99 & $-2.854^{* * *}$ & $-2.992 * *$ & $-2.950^{*}$ & I(1) \\
\hline & XPCOF & -0.164 & -1.646 & -2.62 & $-4.704^{* * *}$ & $-4.604^{* * *}$ & $-4.443^{* *}$ & I(1) \\
\hline \multirow{10}{*}{ KENYA } & EXC & -3.287 & 0.072 & 0.552 & 5.387 & 4.23 & 2.8 & I(1) \\
\hline & INF & 4.664 & 5.917 & 5.095 & & & & $\mathrm{I}(0)$ \\
\hline & TRAC & 0.946 & 1.719 & 1.018 & $5.128 *$ & $3.786^{*}$ & $1.619 *$ & I(1) \\
\hline & TR & 0.443 & 0.967 & 3.77 & $7.874 * *$ & $6.067 * * *$ & $4.948 * *$ & I(1) \\
\hline & RT & 4.204 & 2.805 & 2.096 & & & & $\mathrm{I}(0)$ \\
\hline & XPF\&N & 4.384 & 2.341 & 1.323 & $8.085^{*}$ & $6.535^{*}$ & $5.227 *$ & I(1) \\
\hline & XPVEG & -3.516 & 1.775 & 1.101 & $5.275^{* * *}$ & $-4.734^{*}$ & $3.899 * *$ & I(1) \\
\hline & XPSUG & -0.734 & -3.259 & -4.35 & 8.453* & $6.676^{*}$ & $5.054^{*}$ & I(1) \\
\hline & XPCOA & 0.335 & -1.243 & -2.5 & $-5.515^{* * *}$ & $-5.526^{* * *}$ & $-5.460^{* * *}$ & I(1) \\
\hline & XPCOF & -0.144 & -2.501 & -3.31 & $-1.767 *$ & $-1.709 * *$ & $-2.221 * *$ & I(1) \\
\hline
\end{tabular}

$*, * *, * * *$ indicate level of significant at $10 \%, 5 \%, 1 \%$

J. Hum. Soc. Sci. Crtv. Arts 2019, 14: 91-112 
Data on all the variables are collected for the 5 African countries over the period 1995-2015. D ata on export of the selected agriculture products were obtained from United Nations Conference on Trade and Development (UNCTAD) while data on official exchange rate, inflation rate, taxes on export, interest rate and numbers of tractors across the five countries was gotten from World Development Indicator (WD I), online version of 2018 .

Table 1 shows the unit root result for all the series and all the countries. Starting with South Africa, the result shows that tractors is stationary at level, this implies that the variable (tractors) at its level form is stable. However, exchange rate, export tax, interest rate, inflation rate, and all the agriculture export products considered are stationary at first difference, suggesting that these variables at their level form are unstable. In the case of Nigeria, the result shows that interest rate and tractors are stationary at level. Also, exchange rate, export tax, inflation and all agriculture products are stationary at first difference. In E gypt, inflation rate was stationary at level while other series are stationary at first difference. The result of the unit root test of the series in Ghana indicates that inflation is stationary at level while other series are stationary at first difference. In Kenya, all the series are not stationary at level, even when trend and constant are considered.

\section{Model E stimation Result}

Following the result of the unit root test, it is clear that the appropriate technique is the autoregressive distributed lag because of its ability to successfully estimate models of series with different level of stationarity. Subsequently, the results of the ARDL are presented. The results are presented by products for all the countries. Table 2 shows the result of exchange rate effects on cocoa, while Table 3 is on coffee, then sugar, vegetable and lastly fruits and nuts in that order are explained in the subsequent tables.

\section{Exchange rate and export of Cocoa}

Table 2 shows the result of the unrestricted ARDL estimates. As revealed in the table, it is only in Egypt and Ghana that previous value of Cocoa positively and significantly affects the present value. Cocoa exports are positively and significantly affected by exchange rate in Nigeria, Kenya and Egypt. Specifically, depreciation is export enhancing for Cocoa products from these countries while appreciation inhibits cocoa exports. This follows the Marshall (1923) and Lerner (1944) basic theory that depreciation of exchange rate makes export cheaper, and increase export. But in G hana and South Afri$\mathrm{ca}$, the converse is the case, that is, depreciation of exchange rate precipitates export of cocoa from these countries. Both contemporaneous and previous inflation rate matter significantly for export of cocoa in Kenya and Egypt, and it is the case that lagged inflation rate dwarfs cocoa exports in Kenya while current inflation rate enhances cocoa export in the country. In Egypt, both previous and present inflation rate positively affect cocoa export. This implies that it takes a year before export of cocoa respond negatively to inflation rate in Kenya, while the nature of inflation rate in Egypt is not so much as to make cocoa export less competitive.

Current interest rate is detrimental to cocoa export in Nigeria, and Kenya but it is more pronounced in Nigeria. Egypt's interest rate has positive and significant effect on cocoa export while no significant effect was observed in Ghana and South Africa. Further, 
EFFECTS OF EXCHANGE RATE MOVEMENTS ON EXPORT OF SOME...

export tax have adverse effect on cocoa export in Kenya and Ghana, suggesting that tax adds to cost of exporting cocoa in those countries. It is interesting to note that provision of agricultural tools, in this case, tractor have diverse effect on cocoa export across these emerging markets in terms of duration. In Nigeria and South Africa, it will take a year before the positive effect of agriculture facilities could be felt on the export of cocoa, with South Africa cocoa export more responsive to the provision of these facilities than Nigeria. In the other countries, contemporaneous effect of agriculture facility is felt on the cocoa export. Of particular interest is the case of South Africa where both lagged and current period effect of agriculture facility is felt on cocoa export.

The summary of this finding is that cocoa export is affected mostly by exchange rate across the emerging countries of Africa. D epreciation facilitates cocoa exports in $\mathrm{Ni}$ geria, Kenya and Egypt

Table 2: Co-integrating form/ Parsimonious ECM of the effects of exchange rate on cocoa exports

\begin{tabular}{|c|c|c|c|c|c|}
\hline VARIABLES & NIGERIA & KENYA & EYGPT & GHANA & $\begin{array}{l}\text { SOUTH } \\
\text { AFRICA }\end{array}$ \\
\hline COINTEQ01 & $\begin{array}{l}-0.141^{*} \\
((0.043)\end{array}$ & $\begin{array}{c}-0.727^{*} \\
(0.083)\end{array}$ & $\begin{array}{c}-0.182 * \\
(0.091)\end{array}$ & $\begin{array}{c}-0.523^{* *} \\
(0.058)\end{array}$ & $\begin{array}{c}-0.762^{* * *} \\
(0.004)\end{array}$ \\
\hline $\mathrm{D}(\mathrm{COCOA}(-1))$ & $\begin{array}{l}-1.408 \\
(0.542)\end{array}$ & $\begin{array}{c}0.503 \\
(0.2311)\end{array}$ & $\begin{array}{c}0.4825^{* *} \\
(0.021)\end{array}$ & $\begin{array}{l}-1.336 * \\
(0.101)\end{array}$ & $\begin{array}{c}0.237 \\
(0.029)\end{array}$ \\
\hline $\mathrm{D}(\mathrm{EXR})$ & $\begin{array}{c}0.202^{*} \\
(0.07 \mathrm{~b} 2)\end{array}$ & $\begin{array}{c}2.742)^{* *} \\
(0.039)\end{array}$ & $\begin{array}{c}6.467 * * * \\
(0.005)\end{array}$ & $\begin{array}{c}-3.092 * \\
(0.084)\end{array}$ & $\begin{array}{c}-1.464^{*} \\
(0.071)\end{array}$ \\
\hline $\mathrm{D}(\operatorname{EXR}(-1))$ & $\begin{array}{c}0.75 \\
(0.468)\end{array}$ & $\begin{array}{c}5.262 * * \\
(0.018)\end{array}$ & $\begin{array}{c}2.652 \\
(0.145)\end{array}$ & $\begin{array}{c}2.727632 \\
(0.0608)\end{array}$ & $\begin{array}{c}2.108^{* *} \\
(0.034)\end{array}$ \\
\hline $\mathrm{D}(\mathrm{INF})$ & $\begin{array}{l}-0.061 \\
(0.363)\end{array}$ & $\begin{array}{c}0.015^{* * *} * \\
(0.008)\end{array}$ & $\begin{array}{l}0.198^{*} \\
(0.082)\end{array}$ & $\begin{array}{l}-0.001 \\
(0.849)\end{array}$ & $\begin{array}{c}0.082 \\
(0.181)\end{array}$ \\
\hline $\mathrm{D}(\mathrm{INF}-1)$ & $\begin{array}{c}0.06 \\
(0.392)\end{array}$ & $\begin{array}{c}-0.021 * * \\
(0.058)\end{array}$ & $\begin{array}{l}0.084^{* *} \\
(0.014)\end{array}$ & $\begin{array}{c}0.008 \\
(0.238)\end{array}$ & $\begin{array}{c}-0.294^{* *} \\
(0.03)\end{array}$ \\
\hline $\mathrm{D}(\mathrm{INT})$ & $\begin{array}{c}-0.102^{* *} \\
(0.035)\end{array}$ & $\begin{array}{l}-0.010 * \\
(0.091)\end{array}$ & $\begin{array}{l}0.109 * \\
(0.072)\end{array}$ & $\begin{array}{c}0.042 \\
(0.174)\end{array}$ & $\begin{array}{c}0.087 \\
(0.265)\end{array}$ \\
\hline $\mathrm{D}(\mathrm{INT}(-1))$ & $\begin{array}{c}0.114 \\
(0.402)\end{array}$ & $\begin{array}{c}0.022 \\
(0.561)\end{array}$ & $\begin{array}{l}-0.345 \\
(0.675)\end{array}$ & $\begin{array}{c}0.038 \\
(0.184)\end{array}$ & $\begin{array}{l}-0.063 \\
(0.313)\end{array}$ \\
\hline $\mathrm{D}(\mathrm{TR})$ & $\begin{array}{c}1.607 \\
(0.373)\end{array}$ & $\begin{array}{c}-0.087 * * * \\
(0.002)\end{array}$ & $\begin{array}{c}0.58 \\
(0.614)\end{array}$ & $\begin{array}{c}-0.012^{* *} \\
(0.03)\end{array}$ & $\begin{array}{c}-0.161 \\
(0.641)\end{array}$ \\
\hline $\mathrm{D}(\mathrm{TR}(-1))$ & $\begin{array}{l}0.499 \\
(0.54)\end{array}$ & $\begin{array}{c}0.053 \\
(0.378)\end{array}$ & $\begin{array}{c}0.341 \\
(0.1331)\end{array}$ & $\begin{array}{c}0.049218 \\
(0.0996)\end{array}$ & $\begin{array}{c}-0.132035 \\
(0.4226)\end{array}$ \\
\hline $\mathrm{D}(\mathrm{TRACT})$ & $\begin{array}{l}-5.024 \\
(0.767)\end{array}$ & $\begin{array}{c}-55.185 * * \\
(0.045)\end{array}$ & $\begin{array}{l}40.044^{*} \\
(0.0821)\end{array}$ & $\begin{array}{l}4.121 * \\
(0.081)\end{array}$ & $\begin{array}{c}-35.524^{* * *} \\
-0.0005\end{array}$ \\
\hline D(TRACT(-1)) & $\begin{array}{c}16.696 * * \\
(0.015)\end{array}$ & $\begin{array}{c}-164.202 \\
(0.16)\end{array}$ & $\begin{array}{c}44.733 \\
(0.1146)\end{array}$ & $\begin{array}{c}-0.572 \\
(0.6028)\end{array}$ & $\begin{array}{c}26.770 * * * \\
(0.001)\end{array}$ \\
\hline C & $\begin{array}{c}28.589 * * * \\
(0.0096)\end{array}$ & $\begin{array}{c}-74.57 * * \\
(0.014)\end{array}$ & $\begin{array}{c}188.333 * * \\
(0.043)\end{array}$ & $\begin{array}{c}-129.870^{* *} \\
(0.0451)\end{array}$ & $\begin{array}{c}141.992 * * * \\
(0.003)\end{array}$ \\
\hline R-squared & 0.98 & 0.98 & 0.977 & 0.92825 & 0.944 \\
\hline Adjusted R-squared & 0.98 & 0.98 & 0.865 & 0.956953 & 0.945 \\
\hline
\end{tabular}

$*, * *, * * *$ indicate significant at $10 \%, 5 \%, 1 \%$; figures in parentheses are probability values 
while it discourages cocoa exports in G hana the current year in Nigeria, while $72 \%, 18 \%$, and South Africa. However, depreciation first inhibits the export of cocoa in South Africa but, it enhances it later. Other factors that affect cocoa export in these countries are not significantly uniform. But agriculture infrastructure is important for cocoa exports in these countries.

The speed of convergence is notable in all these countries. According to the long run convergence coefficient, a shock to this model will cause cocoa export in Nigeria, Kenya, Egypt, Ghana and South Africa to respond to the tune of $14 \%, 72 \%, 18 \%$, $52 \%$ and $76 \%$ respectively. This suggests that $14 \%$ of the shock will be absorbed in $52 \%$, and $76 \%$ will be absorbed in other four countries in that order. Hence, it will take more than 7 years (including the current year) for cocoa export in Nigeria to fully adjust to any shock. Whereas it will take less than two years (from the current year) for the full adjustment to disturbance in the system in the case of Kenya and Ghana.

\section{Exchange rate and Coffee exports}

From the result shown in Table 3, past export of coffee positively and significantly affect current export of the product in Nigeria and Ghana. In other countries, the lagged value show positive sign but not significant.

Table 3: Co-integrating form/ Parsimonious ECM of the effects of exchange rate on Coffee exports

\begin{tabular}{|c|c|c|c|c|c|}
\hline VARIABLES & NIGERIA & KENYA & EYGPT & GHANA & SOUTH AFRICA \\
\hline COINTEQ 01 & $\begin{array}{l}-0.812 \\
(0.013)\end{array}$ & $\begin{array}{l}-0.985^{*} \\
(0.074)\end{array}$ & $\begin{array}{c}-0.128^{*} \\
(0.0721)\end{array}$ & $\begin{array}{l}-0.514^{*} \\
(0.079)\end{array}$ & $\begin{array}{c}-0.530^{* *} \\
(0.012)\end{array}$ \\
\hline $\mathrm{D}(\mathrm{COFFE}(-1))$ & $\begin{array}{l}0.5629 * * \\
(0.0447)\end{array}$ & $\begin{array}{l}-1.703 \\
(0.172)\end{array}$ & $\begin{array}{l}-5.843 \\
(0.590)\end{array}$ & $\begin{array}{l}0.485^{*} \\
(0.092)\end{array}$ & $\begin{array}{c}0.469 \\
(0.151)\end{array}$ \\
\hline $\mathrm{D}(\mathrm{EXR})$ & $\begin{array}{c}0.635 \\
(0.591)\end{array}$ & $\begin{array}{c}-0.711 \\
(0.6329)\end{array}$ & $\begin{array}{c}0.39 \\
(0.580)\end{array}$ & $\begin{array}{l}-0.556 \\
(0.706)\end{array}$ & $\begin{array}{c}-1.625 \\
(0.1083)\end{array}$ \\
\hline $\mathrm{D}(\operatorname{EXR}(-1))$ & $\begin{array}{l}1.657 * * \\
(0.034)\end{array}$ & $\begin{array}{c}3.730963 \\
(0.153)\end{array}$ & $\begin{array}{c}1.719 \\
(0.564)\end{array}$ & $\begin{array}{l}0.794^{* *} \\
(0.012)\end{array}$ & $\begin{array}{c}1.188 \\
(0.330)\end{array}$ \\
\hline $\mathrm{D}(\mathrm{INF})$ & $\begin{array}{l}-0.003^{*} \\
(0.094)\end{array}$ & $\begin{array}{l}-0.033 \\
(0.490)\end{array}$ & $\begin{array}{c}2.116 \\
(0.562)\end{array}$ & $\begin{array}{l}-0.009 \\
(0.437)\end{array}$ & $\begin{array}{c}0.073897 \\
(0.307)\end{array}$ \\
\hline $\mathrm{D}(\mathrm{INF}(-1))$ & $\begin{array}{c}0.034 \\
(0.581)\end{array}$ & $\begin{array}{l}-0.007 \\
(0.699)\end{array}$ & $\begin{array}{l}-2.994 \\
(0.390)\end{array}$ & $\begin{array}{l}0.023^{*} \\
(0.060)\end{array}$ & $\begin{array}{c}-0.17887 \\
(0.184)\end{array}$ \\
\hline $\mathrm{D}(\mathrm{INT})$ & $\begin{array}{l}-0.046 \\
(0.725)\end{array}$ & $\begin{array}{l}-0.079 \\
(0.310)\end{array}$ & $\begin{array}{c}5.497 \\
(0.566)\end{array}$ & $\begin{array}{c}0.271 * * * \\
(0.007)\end{array}$ & $\begin{array}{c}0.054137 \\
(0.679)\end{array}$ \\
\hline $\mathrm{D}(\mathrm{INT}(-1))$ & $\begin{array}{c}0.077 \\
(0.510)\end{array}$ & $\begin{array}{c}0.012 \\
(0.618)\end{array}$ & $\begin{array}{l}-2.571 \\
(0.555)\end{array}$ & $\begin{array}{c}-0.121^{* *} \\
(0.028)\end{array}$ & $\begin{array}{l}-0.079 \\
(0.197)\end{array}$ \\
\hline $\mathrm{D}(\mathrm{TR})$ & $\begin{array}{l}-1.913 \\
(0.241)\end{array}$ & $\begin{array}{l}-0.09 \\
(0.180)\end{array}$ & $\begin{array}{l}-5.004 \\
(0.465)\end{array}$ & $\begin{array}{c}0.051 \\
(0.186)\end{array}$ & $\begin{array}{l}-0.071 \\
(0.568)\end{array}$ \\
\hline $\mathrm{D}(\mathrm{TR}(-1))$ & $\begin{array}{c}-0.80243 \\
(0.416)\end{array}$ & $\begin{array}{c}0.074 \\
(0.172)\end{array}$ & $\begin{array}{l}-2.348 \\
(0.532)\end{array}$ & $\begin{array}{c}-0.124^{* *} \\
(0.025)\end{array}$ & $\begin{array}{c}-0.30118 \\
(0.271)\end{array}$ \\
\hline D (TRACT) & $\begin{array}{c}0.879 \\
(0.345)\end{array}$ & $\begin{array}{c}0.323 \\
(0.222)\end{array}$ & $\begin{array}{l}-0.348 \\
(0.562)\end{array}$ & $\begin{array}{l}0.184^{* *} \\
(0.049)\end{array}$ & $\begin{array}{c}-0.829 * * \\
(0.056)\end{array}$ \\
\hline D(TRACT(-1)) & $\begin{array}{c}0.211 \\
(0.528)\end{array}$ & $\begin{array}{c}0.813 \\
(0.310)\end{array}$ & $\begin{array}{l}-0.795 \\
(0.570)\end{array}$ & $\begin{array}{l}-0.511 \\
(0.162)\end{array}$ & $\begin{array}{c}-0.05375 \\
(0.575)\end{array}$ \\
\hline $\mathrm{C}$ & $\begin{array}{c}-10.503^{*} \\
(0.070)\end{array}$ & $\begin{array}{c}-29.937 * * \\
(0.020)\end{array}$ & $\begin{array}{c}532.443^{* *} \\
(0.019)\end{array}$ & $\begin{array}{c}-101.77^{* *} \\
(0.018)\end{array}$ & $\begin{array}{c}135.590^{* *} \\
(0.016)\end{array}$ \\
\hline R-square & 0.94416 & 0.97140 & 0.9841 & 0.97576 & 0.95042 \\
\hline Adj R-Squared & 0.97445 & 0.94849 & 0.71381 & 0.89093 & 0.92691 \\
\hline
\end{tabular}

J. Hum. Soc. Sci. Crtv. Arts 2019, 14: 91-112 
Current exchange rate does not have any significant effect on the export of coffee in any of the countries. Meanwhile, coffee export is being negatively and significantly affected by previous changes in exchange rate in Nigeria, and G hana. Although coffee export shows strong sensitivity to exchange rate changes in Kenya, such sensitivity is not significant and so, coffee exports are not affected by exchange rate changes of Kenya.

The positive and significant effect of exchange rate on coffee export in Nigeria and Ghana conforms with the basic theory that depreciation of exchange rate makes export cheaper, and consequently lead to increase in export of the product. The outcome also suggests that Nigerian and $G$ hanaian coffee are normal goods. In other countries, and particularly Kenya, exchange rate failed to significantly affect coffee export.

Nigeria export of coffee is negatively affected by inflation rate. The implication of this is that the price of Nigeria coffee at the international market makes it less competitive and hence, reduces its demand. Coffee exports from other African countries are not significantly affected by inflation rate. It could be that the price level in these countries has not got to the point where coffee exports will be affected. Meanwhile, a cursory look at the result shows that the direction of effect of inflation rate on coffee export differ across countries. In Egypt and South Africa, the direction of effect was positive, albeit not significant. In other countries, the effect is negative but only in Nigeria was inflation rate really matter for coffee export.

Effect of export tax is insignificant in influencing coffee exports in all the countries under review, although the direction of effect was negative in all the countries except Ghana. An indication of negative export tax warns that this measure will likely add to cost of exporting coffee and this could effectively reduce the export of the product. The use of tractor as input for the production of coffee is insignificant to exporting the product in Nigeria, Kenya and Egypt. The use of the factor input significantly leads to increase in export of coffee from Ghana while it significantly decreases export of the product from South Africa. The negative effect in the case of South Africa could be due to the applicability of the machine in the production of coffee in the country.

The co-integerating coefficient is negative and significant for all the countries, implying that long run relationship exists in the model. Like it was discovered in the case of cocoa export, rate of convergence in coffee exports differ across countries, with Kenya and Nigeria being the fastest in that order. The rate of convergence is very slow in Egypt as the system will adjust by $12 \%$ in the present year while the rest $78 \%$ will have to be done in the succeeding years. Hence, it will take more than 6 years from now for the system to fully adjust to a new equilibrium. In Kenya, it will take less than 2 years for the adjustment to complete while in $\mathrm{G}$ hana and South Africa, it will take around 2 year.

\section{Exchange rate and Sugar exports}

Sugar export from Nigeria is positively and significantly affected by current exchange rate, suggesting that increase in volume of naira per unit of foreign currency will yield increase in sugar export (Table 4). In Kenya and G hana, it will take a year before the impact of exchange rate is felt on the export of sugar while no significant effect is observed in Egypt. It is also observed that previous 
depreciation helps sugar export to increase in Kenya and Ghana. Hence, it can be concluded that depreciation is good for sugar export in most emerging markets of Africa.

Interest rate is an important driver of sugar export in all the countries except Egypt. Interest rate exerts negative effect on sugar export in all the countries and it was mostly pronounced in Kenya. Hence, interest rate is mostly sensitive to export of sugar in Kenya, followed by Egypt and less pronounced in Nigeria. However, previous interest rate positively and significantly affects sugar export in Nigeria and South Africa while it negatively and significantly affects export of the product in Kenya.

Table 4: Co-integrating form/ Parsimonious ECM of the effects of exchange rate on Sugar exports

\begin{tabular}{|c|c|c|c|c|c|}
\hline VARIABLES & NIGERIA & KENYA & EYGPT & GHANA & SOUTH AFRICA \\
\hline \multirow{2}{*}{ COINTEQ 01} & $-0.340 * *$ & $-0.845^{* *}$ & $0.143^{* *}$ & $-0.559 * * *$ & $-0.449 * * *$ \\
\hline & $(0.005)$ & $(0.021)$ & $(0.0301)$ & $(0.003)$ & $(0.004)$ \\
\hline \multirow{2}{*}{$\mathrm{D}(\mathrm{EXR})$} & $0.884^{* *}$ & -17.135 & 12.388 & -0.032 & 0.612407 \\
\hline & $(0.055)$ & $(0.164)$ & $(0.511)$ & $(0.95)$ & $(0.268)$ \\
\hline \multirow{2}{*}{$\mathrm{D}(\operatorname{EXR}(-1))$} & -2.982 & $2.016^{*}$ & -0.8950 & $4.998^{* *}$ & 0.136 \\
\hline & $(0.084)$ & $(0.076)$ & $(0.379)$ & $(0.020)$ & $(0.850)$ \\
\hline \multirow{2}{*}{$\mathrm{D}(\mathrm{INF})$} & $-0.032 *$ & $-1.736 *$ & -0.632 & 0.008 & $-0.165 * *$ \\
\hline & $(0.072)$ & $(0.060)$ & $(0.350)$ & $(0.116)$ & $(0.028)$ \\
\hline \multirow{2}{*}{$\mathrm{D}(\mathrm{INF}(-1))$} & $0.043^{* *}$ & $-0.795 *$ & 0.711 & 0.003 & $0.147^{* *}$ \\
\hline & $(0.017)$ & $(0.063)$ & $(0.267)$ & $(0.377)$ & $(0.056)$ \\
\hline \multirow{2}{*}{$\mathrm{D}(\mathrm{INT})$} & $-0.071 * *$ & $-2.196 *$ & -1.223 & $-0.083^{* *}$ & $-0.259 * * *$ \\
\hline & $(0.040)$ & $(0.056)$ & $(0.909)$ & $(0.040)$ & $(0.006)$ \\
\hline \multirow{2}{*}{ D(INT(-1)) } & $0.0749 * *$ & $-0.734 *$ & 0.519 & $0.103^{*}$ & $0.211 * * *$ \\
\hline & $(0.019)$ & $(0.082)$ & $(0.370)$ & (0.028) & $(0.005)$ \\
\hline \multirow{2}{*}{$\mathrm{D}(\mathrm{TR})$} & $0.006^{* *}$ & 0.502 & 1.035 & $-0.035^{* *}$ & -0.209 \\
\hline & $(0.029)$ & $(0.130)$ & $(0.420)$ & $(0.051)$ & $(0.430)$ \\
\hline \multirow[t]{2}{*}{$\mathrm{D}(\mathrm{TR}(-1))$} & $-0.992 * * *$ & 0.121 & 0.598 & $-0.033 * *$ & -0.132 \\
\hline & $(0.009)$ & (0.377) & $(0.410)$ & $(0.053)$ & $(0.420)$ \\
\hline \multirow[t]{2}{*}{$\mathrm{D}(\mathrm{TRACT})$} & -1.048 & 35.765 & 110.191 & 1.719 & -5.615 \\
\hline & $(0.744)$ & $(0.213)$ & $(0.507)$ & $(0.159)$ & $(0.185)$ \\
\hline \multirow{2}{*}{ D (TRACT(-1)) } & 4.3040 & -93.443 & 0.20401 & -1.207 & $1.723 * *$ \\
\hline & (0.197) & $(0.180)$ & $(0.322)$ & $(0.337)$ & (0.011) \\
\hline \multirow{2}{*}{ C } & $2.2095 * *$ & $1.0083^{* * *}$ & 1.0333 & $2.482 *$ & 1.8710 \\
\hline & $(0.028)$ & $(0.005)$ & (1.995) & $(0.077)$ & $(0.065)$ \\
\hline R-square & 0.99 & 0.82 & 0.96 & 0.96 & 0.97 \\
\hline Adj R-Squared & 0.98 & 0.35 & 0.92 & 0.95 & 0.87 \\
\hline
\end{tabular}

$*, * *, * * *$ indicate significant at $10 \%, 5 \%, 1 \%$; figures in parentheses are probability values

No significant effect of interest rate was to sugar export in Nigeria, Kenya and South observed in the export of sugar from Africa while previous inflation significantly Egypt. Current inflation rate is detrimental promotes sugar exports in these countries 
except Kenya where both lagged and contemporaneous inflation rate dwarfs sugar export. No effect of inflation rate, both current and previous, was observed on the sugar export from Egypt and G hana.

This could suggest that prices of sugar in these countries has not risen to the level at which adverse effect will set in. The speed of convergence is fastest in Kenya, followed by Ghana and then South Africa. This implies that export of sugar reacts to disturbance differently across countries.

\section{Exchange rate and vegetable exports}

Table 5 presents the result of the drivers of vegetable exports with special attention to exchange rate changes. Previous export drags current export of vegetable in Nigeria and South Africa. In Kenya, there is a positive and significant effect of lagged value of vegetable export on the current export. Hence, exporters of vegetable products in Kenya are motivated in the current year following the export experienced in the earlier year. In Egypt and G hana, there was no evidence of contemporaneous export of vegetable to be affected by the previous one.

Current exchange rate significantly affects vegetable exports in all the countries but the direction of effects differ. In Nigeria, Kenya and Egypt, the effect is positive while the effect is negative in G hana and South Africa. Hence, depreciation encourages export of vegetable from Nigeria, Kenya and Egypt but discourages it in G hana and South Africa. Also, the previous exchange rate changes have positive and sig- nificant effect on the export of vegetable in Nigeria, Kenya and South Africa. Hence, exchange rate movement is very important for export of vegetable in the emerging markets of Africa.

However, it can be said that while vegetable products in Nigeria, Kenya and Egypt are normal good, because as real income of the foreigners (caused by depreciation) increases more of vegetable exports from these countries are demanded for, the products are inferior (since it reduces as exchange rate depreciates) in Ghana and South Africa. Vegetable exports respond negatively and significantly to inflation rate in Nigeria, Kenya and G hana but in South Africa, vegetable export increases as inflation rises. What this mean is that in the first two countries, inflation has reached a level at which it makes export of vegetable less competitive in the world market while in the last country, the rate of inflation is not so high that it could cause reduction in vegetable export.

There is no evidence of significant effect of inflation rate on vegetable export from Egypt. Meanwhile, previous inflation rate is good for vegetable export in Kenya. What this implies is that initially, inflation inhibits vegetable exports but it later improves it. In South Africa, initial increase in inflation rate is export supporting but the increase this year precipitate next year export of vegetable. Thus, as previous inflation rate is export enhancing in Kenya, it is export inhibiting in South Africa. In Nigeria, Egypt and Ghana, no effect of previous inflation rate was detected on vegetable exports. 


\begin{tabular}{|c|c|c|c|c|c|}
\hline VARIABLES & NIGERIA & KENYA & EYGPT & GHANA & SOUTH AFRICA \\
\hline & $-0.557 * * *$ & $-0.833^{* * *}$ & $-0.531 * *$ & $-0.769 * * *$ & $-0.310^{* * *}$ \\
\hline COINTEQ 01 & $(0.012)$ & $(0.007)$ & $(0.043)$ & $(0.015)$ & $(0.006)$ \\
\hline \multirow{2}{*}{$\mathrm{D}(\mathrm{VEG}(-1))$} & $-0.660^{*}$ & $0.5531 *$ & -0.459 & 0.368 & $-0.346 * *$ \\
\hline & $(0.079)$ & $(0.077)$ & (0.189) & $(0.180)$ & $(0.008)$ \\
\hline \multirow{2}{*}{$\mathrm{D}(\mathrm{EXC})$} & $0.736^{*}$ & $3.559 * * *$ & $5.577^{*}$ & $-1.436^{*}$ & $-1.834^{* * *}$ \\
\hline & $(0.056)$ & $(0.002)$ & (0.099) & $(0.098)$ & $(0.002)$ \\
\hline \multirow{2}{*}{$\mathrm{D}(\mathrm{EXC}(-1))$} & 3.149* & $2.015^{* *}$ & -1.776 & -1.39 & $0.681^{*}$ \\
\hline & $(0.080)$ & $(0.015)$ & $(0.692)$ & $(0.232)$ & $(0.089)$ \\
\hline \multirow{2}{*}{$\mathrm{D}(\mathrm{INF})$} & $-0.099 *$ & $-0.058 * * *$ & -0.121 & $-0.018^{*}$ & $0.171 * * *$ \\
\hline & $(0.089)$ & $(0.002)$ & $(0.348)$ & $(0.061)$ & $(0.001)$ \\
\hline \multirow{2}{*}{$\mathrm{D}(\mathrm{INF}(-1))$} & 0.07 & $0.922 *$ & 0.162 & 0.001 & $-0.233 * * *$ \\
\hline & $(0.114)$ & $(0.070)$ & (0.309) & $(0.6467)$ & $(0.001)$ \\
\hline \multirow{2}{*}{$\mathrm{D}(\mathrm{RT})$} & -0.119 & $-0.054^{* * *}$ & $-0.029 *$ & $0.113^{* *}$ & $0.131^{* * *}$ \\
\hline & $(0.101)$ & $(0.004)$ & $(0.083)$ & $(0.040)$ & $(0.006)$ \\
\hline \multirow{2}{*}{$\mathrm{D}(\mathrm{RT}(-1))$} & 0.115 & 0.990* & 0.054 & -0.021 & $-0.297 * * *$ \\
\hline & $(0.117)$ & $(0.09)$ & $(0.494)$ & $(0.378)$ & $(0.001)$ \\
\hline \multirow{2}{*}{$\mathrm{D}(\mathrm{TR})$} & $4.773^{*}$ & $-0.005^{*}$ & 0.313 & 0.006 & $-0.062 *$ \\
\hline & (0.067) & (0.098) & $(0.312)$ & $(0.527)$ & $(0.066)$ \\
\hline \multirow{2}{*}{$\mathrm{D}(\mathrm{TR}(-1))$} & $0.766^{*}$ & -0.014 & $0.320 * *$ & $0.058^{* *}$ & -0.75 \\
\hline & $(0.083)$ & (0.132) & $(0.021)$ & (0.033) & $(0.960)$ \\
\hline \multirow{2}{*}{$\mathrm{D}$ (TRAC) } & $-0.7290 *$ & $0.5690 * *$ & $0.400 *$ & $0.066^{* *}$ & $-0.284 * * *$ \\
\hline & $(0.078)$ & $(0.056)$ & $(0.062)$ & $(0.027)$ & (0.001) \\
\hline \multirow{2}{*}{ D (TRAC(-1)) } & $0.2600 *$ & -0.420 & -0.8270 & -1.869 & $1.857 * * *$ \\
\hline & $(0.074)$ & $(0.430)$ & (0.397) & (0.353) & $(0.002)$ \\
\hline \multirow[t]{2}{*}{ C } & $-5.4805^{* * *}$ & $-4.3640 * *$ & $-1.586 * * *$ & $-6.294^{* *}$ & $0.0021 * * *$ \\
\hline & $(0.019)$ & $(0.043)$ & $(0.006)$ & $(0.044)$ & $(0.005)$ \\
\hline R-square & 0.99 & 0.99 & 0.99 & 0.99 & 0.99 \\
\hline Adj R-Squared & 0.99 & 0.99 & 0.99 & 0.96 & 0.98 \\
\hline
\end{tabular}
$*, * *, * * *$ indicate significant at $10 \%, 5 \%, 1 \%$; figures in parentheses are probability values

As inflation rate is harmful to vegetable export in Kenya so also is interest rate. In Ghana and South Africa, interest rate positively and significantly affects vegetable exports. Hence, cost of borrowing tends not to be a binding constraint to vegetable exports in these countries. The converse, however is the case in Kenya and Egypt where it was found that interest rate strangulates vegetable export. Although a negative sign appear in the case of Nigeria, it is not significant and hence, interest rate is not also a binding constraint to vegetable export in Nigeria. The reason for insignificance is that perhaps most vegetable farmers finance vegetable production through other source of financing such as cooperative society, own income or borrowing from friends and relations. Meanwhile, the negative sign suggests that as more and more farmers access interest-paying loan, it will dwarf export of vegetable products. 
EFFECTS OF EXCHANGE RATE MOVEMENTS ON EXPORT OF SO ME...

Table 6: Co-integrating form/ Parsimonious ECM of the effects of exchange rate on Fruits and Nuts exports

\begin{tabular}{|c|c|c|c|c|c|}
\hline VARIABLES & NIGE RIA & KENYA & EYGPT & GHANA & $\begin{array}{l}\text { SOUTH } \\
\text { AFRICA }\end{array}$ \\
\hline \multirow{2}{*}{ COINTEQ 01} & $-0.533^{* *}$ & $-0.601^{* *}$ & $-0.02861^{* *}$ & $-0.580^{* *}$ & $-0.536^{* *}$ \\
\hline & $(0.067)$ & $(0.053)$ & $(0.0197)$ & $(0.050)$ & $(0.01)$ \\
\hline \multirow{2}{*}{$\mathrm{D}(\mathrm{EXC})$} & $-0.166^{*}$ & -1.796 & 0.4586 & -0.7898 & $0.303^{*}$ \\
\hline & $(0.068)$ & $(0.155)$ & $(0.880)$ & $(0.255)$ & $(0.090)$ \\
\hline \multirow{2}{*}{$\mathrm{D}(\mathrm{EXC}(-1))$} & $-1.346 * *$ & 3.050932* & -12.4193 & $-3.405^{*}$ & $-1.058 * *$ \\
\hline & $(0.037)$ & $(0.064)$ & $(0.456)$ & $(0.07)$ & $(0.011)$ \\
\hline \multirow{2}{*}{$\mathrm{D}(\mathrm{INF})$} & 0.119828 & 0.04598 & -0.27295 & -0.0022 & -0.018 \\
\hline & $(0.208)$ & $(0.114)$ & $(0.382)$ & (0.693) & $(0.182)$ \\
\hline \multirow{2}{*}{$\mathrm{D}(\mathrm{INF}(-1))$} & 0.11983 & $0.052^{*}$ & 0.353847 & 0.0058 & $0.143863^{* *}$ \\
\hline & $(0.202)$ & $(0.062)$ & (0.373) & $(0.302)$ & $(0.018)$ \\
\hline \multirow{2}{*}{$\mathrm{D}(\mathrm{RT})$} & 0.199 & 0.052 & -0.433 & 0.0814 & $-0.112^{* *}$ \\
\hline & $(0.211)$ & $(0.127)$ & $(0.459)$ & $(0.163)$ & $(0.012)$ \\
\hline \multirow{2}{*}{$\mathrm{D}(\mathrm{RT}(-1))$} & $-0.013 * *$ & $-0.0423^{*}$ & -0.2055 & $-0.125^{* *}$ & $-0.073^{* *}$ \\
\hline & $(0.031)$ & $(0.065)$ & $(0.451)$ & $(0.055)$ & $(0.010)$ \\
\hline \multirow{2}{*}{$\mathrm{D}(\mathrm{TR})$} & -0.524 & $-0.066^{*}$ & 0.374 & -0.018 & $0.544^{* *}$ \\
\hline & $(0.218)$ & $(0.059)$ & $(0.519)$ & $(0.451)$ & $(0.014)$ \\
\hline \multirow{2}{*}{$\mathrm{D}(\mathrm{TR}(-1))$} & $0.419 * *$ & $0.087548^{* *}$ & 0.296578 & -0.014 & $-0.426 * * *$ \\
\hline & $(0.014)$ & $(0.047)$ & $(0.445)$ & $(0.320)$ & $(0.009)$ \\
\hline \multirow{2}{*}{ D (TRAC) } & 0.10589 & $0.220966 *$ & 0.522 & 0.81347 & $-0.254^{* * *}$ \\
\hline & $(0.208)$ & $(0.07)$ & $(0.956)$ & $(0.167)$ & $(0.005)$ \\
\hline \multirow{2}{*}{ D (TRAC(-1)) } & 0.693976 & 0.73067 & 0.95884 & -0.2444 & $0.997 * *$ \\
\hline & $(0.171)$ & $(0.128)$ & $(0.515)$ & $(0.124)$ & $(0.024)$ \\
\hline \multirow{2}{*}{ C } & $36.976^{* *}$ & $-39.455^{* *}$ & 102.99 & $-81.351 *$ & $4.695^{* *}$ \\
\hline & $(0.021)$ & $(0.062)$ & $(0.621)$ & $(0.09) 3$ & $(0.058)$ \\
\hline R-square & 0.94 & 0.96 & 0.97 & 0.95 & 0.91 \\
\hline Adj R-Squared & 0.90 & 0.92 & 0.93 & 0.91 & 0.89 \\
\hline
\end{tabular}

$*, * *, * * *$ indicate significant at $10 \%, 5 \%, 1 \%$; figures in parentheses are probability values

Tractor is very important in the production and export of vegetable products in all the countries under review. However, in Nigeria and South Africa, the use of tractor is significantly harmful for the export of vegetable. This could be the case if it is highly expensive to access the use of the machine. In other countries, the use of tractor is export enhancing. Meanwhile, access to tractor last year helps this year's export of vegetable to increase in Nigeria and South Africa.
Exchange rate and Fruits and N uts Exports

Exchange rate depreciation decreases export of fruits and nuts in Nigeria but increase export of the products in South Africa. (Table 6) In the rest of the countries, exchange rate plays no role in influencing exports of fruits and nuts, but a sign of increase following depreciation in shown in Egypt. Meanwhile if depreciation occurred in the previous year, export of fruits and nuts will increase in the current year in Ken- 
ya. In other countries, previous depreciation of currency strangulates current export of the product. This implies that fruits and nuts farmers will be better off when exchange rate of Kenya depreciates while they will be worse off if depreciation occurs in Nigeria, Ghana and South Africa. O ne reason why depreciation could be detrimental for fruits and nuts is that the factor input used to process fruits are imported and so, depreciation could make the import input expensive and by implication lessens the amount exported.

The use of tractor in the production of fruits and nuts does not effectively influence export of fruits and nuts in Nigeria, Egypt and Ghana. South African's export of fruits and nuts respond positively to the use of tractor.

Table 7a: Long run effects of exchange rate on the exports of selected agriculture products

\begin{tabular}{|c|c|c|c|c|c|}
\hline Variables & COFFEE & SUGAR & $\begin{array}{c}\text { FRUITS } \\
\text { AND NUTS }\end{array}$ & $\begin{array}{l}\text { VEGETA- } \\
\text { BLES } \\
\end{array}$ & COCOA \\
\hline \multirow{2}{*}{ EXR } & $-0.380625^{*}$ & -4.56782 & 0.244727 & $0.977301^{* *}$ & $4.269211^{*}$ \\
\hline & -0.04 & $(0.2414) 1$ & -0.2867 & -0.0345 & -0.0677 \\
\hline \multirow{2}{*}{ INF } & $-0.077487^{>}$ & 0.1597 & $-0.115227^{*}$ & 0.006893 & 0.439661 \\
\hline & -0.0818 & $(0.5201) 4$ & -0.0561 & -0.3746 & -0.996 \\
\hline \multirow{2}{*}{ INT } & -0.184106 & -0.390025 & $-0.179963^{* *}$ & -0.019029 & 0.890161 \\
\hline & -0.1068 & -0.1214 & -0.0499 & -0.3362 & $(0.3651$ \\
\hline \multirow{2}{*}{$\mathrm{TR}$} & -0.168923 & -0.289197 & $1.381306 * *$ & $0.302938 * *$ & -0.625353 \\
\hline & -0.0565 & $(0.7812)$ & -0.0114 & -0.0335 & -0.97 \\
\hline \multirow{2}{*}{ TRACT } & $2.115494^{*}$ & -10.542905 & -2.729124 & $4.878614^{* * *}$ & -4.460235 \\
\hline & -0.0689 & -0.1747 & -0.312 & -0.0188 & -0.7421 \\
\hline $\begin{array}{l}\text { Normality test } \\
\text { (Jack-Bera) }\end{array}$ & $\begin{array}{c}1.796 \\
(0.743)\end{array}$ & $\begin{array}{l}1.130 \\
(0.561)\end{array}$ & $\begin{array}{c}14.60 \\
(0.392)\end{array}$ & $\begin{array}{l}26.192 \\
(0.832)\end{array}$ & $\begin{array}{l}23.295 \\
(0.381)\end{array}$ \\
\hline $\begin{array}{l}\text { Serial correla- } \\
\text { tion test }\end{array}$ & $\begin{array}{c}0.912 \\
(0.114)\end{array}$ & $\begin{array}{c}0.993 \\
(0.327)\end{array}$ & $\begin{array}{c}1.549 \\
(0.661)\end{array}$ & $\begin{array}{c}3.221 \\
(0.151)\end{array}$ & $\begin{array}{l}1.137 \\
(0.44)\end{array}$ \\
\hline $\begin{array}{l}\text { Test for Het- } \\
\text { eroskdasticity }\end{array}$ & $\begin{array}{l}1.423 \\
(0.53)\end{array}$ & $\begin{array}{l}14.219 \\
(0.525)\end{array}$ & $\begin{array}{c}2.221 \\
(0.666)\end{array}$ & $\begin{array}{l}18.032 \\
(0.811\end{array}$ & 21 \\
\hline \multicolumn{6}{|l|}{ KENYA } \\
\hline \multirow[t]{2}{*}{ Variables } & COFFEE & SUGAR & $\begin{array}{c}\text { FRUITS } \\
\text { AND NUTS }\end{array}$ & $\begin{array}{l}\text { VEGETA- } \\
\text { BLES }\end{array}$ & COCOA \\
\hline & $\begin{array}{c}-0.359924 \\
(0.8579)\end{array}$ & $\begin{array}{c}-4.754182 \\
(0.410)\end{array}$ & $\begin{array}{c}-2.614999 \\
(0.108)\end{array}$ & $\begin{array}{c}-3.148463^{* * *} \\
(0.007)\end{array}$ & $\begin{array}{c}-0.905775 \\
(0.7391)\end{array}$ \\
\hline EXR & 0.010972 & 0.009825 & 0.019928* & $-0.069981 * * *$ & 0.077939 \\
\hline \multirow[t]{2}{*}{ INF } & $(0.7353)$ & $(0.821)$ & (0.0863) & $(0.0022)$ & $(0.1403)$ \\
\hline & 0.084689 & 0.255452 & $0.050493^{*}$ & $-0.048107 * * *$ & 0.039490 \\
\hline \multirow[t]{2}{*}{ INT } & 1945) & $(0.127)$ & $(0.0730)$ & $(0.003)$ & $(0.4455)$ \\
\hline & 0.311589 & $-0.722344^{* *}$ & $-0.179856 *$ & 0.028869 & -0.011288 \\
\hline \multirow[t]{2}{*}{ TR } & $(0.2442)$ & $(0.021)$ & $(0.0503)$ & $(0.2377)$ & $(0.9159)$ \\
\hline & 3.857560 & -1.380919*** & 6.512699* & $7.452726 * * *$ & 9.016271 \\
\hline TRACT & $(0.3396)$ & $(0.016)$ & $(0.0580)$ & $(0.001)$ & $(0.1789)$ \\
\hline
\end{tabular}


EFFECTS OF EXCHANGE RATE MOVEMENTS ON EXPORT OF SOME...

\begin{tabular}{|c|c|c|c|c|c|}
\hline $\begin{array}{c}\text { Normality test } \\
\text { (Jack-Bera) }\end{array}$ & $\begin{array}{c}0.827 \\
(0.661)\end{array}$ & $\begin{array}{c}2.232 \\
(0.325)\end{array}$ & $\begin{array}{l}0.760 \\
(0.83)\end{array}$ & $\begin{array}{c}1.818 \\
(0.402)\end{array}$ & $\begin{array}{l}0.762 ? \\
(0.682)\end{array}$ \\
\hline \multirow{2}{*}{$\begin{array}{l}\text { Serial correla- } \\
\text { tion test }\end{array}$} & 12.201 & 8.321 & 19.491 & 23.841 & 11.111 \\
\hline & $(0.458)$ & (0.439) & $(0.581)$ & $(0.771)$ & $(0.382)$ \\
\hline \multirow{2}{*}{$\begin{array}{l}\text { Test for Het- } \\
\text { eroskdasticity }\end{array}$} & 10.102 & 0.981 & 18.351 & 3.320 & 10.516 \\
\hline & $(0.438)$ & (0.143) & $(0.668)$ & $(0.137)$ & $(0.371)$ \\
\hline \multicolumn{6}{|l|}{ EGYPT } \\
\hline \multirow[t]{2}{*}{ Variables } & COFFEE & SUGAR & $\begin{array}{c}\text { FRUITS } \\
\text { AND NUTS }\end{array}$ & $\begin{array}{l}\text { VEGETA- } \\
\text { BLES }\end{array}$ & COCOA \\
\hline & $0.001 *$ & 1.032 & $0.329 * *$ & 0.002 & 3.230970* \\
\hline \multirow[t]{2}{*}{ EXR } & $(0.00)$ & $(0.304)$ & $(0.030)$ & $(0.331)$ & $(0.081)$ \\
\hline & 0.005 & 0.003 & 0.001 & 0.006 & $0.198550 *$ \\
\hline \multirow[t]{2}{*}{ INF } & $(0.115)$ & $(0.437)$ & $(0.302)$ & $(0.417)$ & $(0.063)$ \\
\hline & 0.030 & 0.481 & 0.115 & 0.032 & 0.058299 \\
\hline \multirow[t]{2}{*}{ INT } & $(0.14)$ & (0.921) & $(0.330)$ & $(0.441)$ & $(0.730)$ \\
\hline & 0.110 & 0.001 & 0.060 & 0.111 & -0.668466 \\
\hline \multirow[t]{2}{*}{ TR } & $(0.322)$ & $(0.161)$ & $(0.430)$ & $(0.728)$ & $(0.503)$ \\
\hline & $0.022^{* *}$ & 0.047 & $0.005^{* * *}$ & $0.021 *$ & -16.120457 \\
\hline TRACT & $(0.042)$ & $(0.222)$ & $(0.001)$ & $(0.060)$ & $(0.580)$ \\
\hline \multirow{2}{*}{$\begin{array}{l}\text { Normality test } \\
\text { (Jack-Bera) }\end{array}$} & 2.789 & 1.379 & 1.734 & 1.249 & 3.262 \\
\hline & $(0.174)$ & $(0.201)$ & $(0.310)$ & $(0.535)$ & $(0.152)$ \\
\hline \multirow{2}{*}{$\begin{array}{l}\text { Serial correla- } \\
\text { tion test }\end{array}$} & 10.256 & 1.360 & 10.324 & 2.297 & 2.412 \\
\hline & (0.692) & $(0.332)$ & $(0.430)$ & $(0.527)$ & $(0.740)$ \\
\hline Test for Het- & 23.321 & 16.302 & 3.549 & 21.304 & 2.659 \\
\hline eroskdasticity & $(0.432)$ & $(0.541)$ & $(0.718)$ & $(0.342)$ & (5.553) \\
\hline
\end{tabular}

$*, * *, * * *$ indicate significant at $10 \%, 5 \%, 1 \%$; figures in parentheses are probability values

The summary of the short run results indicate that exchange rate and other factors that determine export of agriculture products differ across countries. Current increase in effective exchange rate (depreciation of domestic currency) increases export of cocoa, sugar and vegetables in Nigeria. Current depreciation also encourages export of cocoa in Egypt. Current depreciation dwarfs export of cocoa in Kenya, Ghana and South Africa.

The result of vegetable shows that there is co-integration among the variables in the long run, for all the countries. This implies that there is convergence among the variables in the long run. The ECM shows the speed of adjustment from short-run dynamics to long-run equilibrium. That is if there is a shock in any of the variables export of vegetables, exchange rate, inflation, interest rate, taxes on export and tractors, will the variables still co-integrate in the long run.

Since there is long run relationship among the variables as demonstrated by the bounds tests, it is imperative to investigate the long run effect. Tables 7a and 7b show the results. In Table 7a, the long run effect of exchange rate and other important variables on the selected products are shown for Nigeria, Kenya and Egypt respectively. For Nigeria, exchange rate has long run negative and significant effect on coffee exports and positive 
effect on vegetables and cocoa. Sugar and fruits and nuts did not respond significantly to change in exchange rate. Hence, this result suggests that in the long run, depreciation increases exports of vegetables and cocoa but reduces exports of coffee. Other factors that have significant effects on these products include inflation rate, export tax and supply of tractors (exports of coffee), export tax, inflation rate, interest rate and tractor supply (on fruits and nuts), and export tax, and supply of tractors (on vegetables).

In Kenya, only vegetable exports are significantly and negatively affected by exchange rate changes in the long run. In this regard, depreciation of real effective exchange rate in Kenya reduces vegetable exports. O ther variables that have significant effects on these products are inflation rate, interest rate, export tax and supply of tractors (fruits and nuts), inflation rate, interest rate and supply of tractors (vegetables), export tax and supply of tractors (on sugar). In the same vein, there is long run effect of exchange rate on exports of coffee, fruits and nuts and cocoa in Egypt. All the products respond positively to changes in exchange rate. Hence, in the long run, exchange rate depreciation enhances exports of coffee, fruits and nuts and cocoa in Egypt. Further, inflation rate has positive and significant effect on export of cocoa while availability of tractors enhances export of coffee, fruits and nuts and vegetables in the long run.

Exchange rate movement matters for agriculture products in Ghana in the long run. As indicated in Table $7 \mathrm{~b}$, exchange rate depreciation increases exports of coffee, fruits and nuts and vegetables in the long run. However, the effect of depreciation on sugar in the long run is negative, suggesting that depreciation reduces export demand of this product. Again, cocoa exports do not respond to exchange rate changes in the long run in G hana. Compared with the short run effect, only coffee export benefit from depreciation both in the short run and long run. Cocoa export reduces following exchange rate depreciation both in the short run and long run. Fruits and nuts and vegetables export decrease in the short run when exchange rate depreciates in $\mathrm{G}$ hana but this will be overturned by increase in the exports of these products in the long run.

Lastly for South Africa, exchange rate depreciation is good for fruits and nuts export in the long run. Given the result of the short run effect of exchange rate on the export of fruit and nuts, it can be conjectured that fruit and nut farmers will benefit significantly from exchange rate depreciation both in the short run and in the long run. Other agriculture products negatively responded to depreciation of exchange rate in this country, except coffee that shows no evidence of significant effect. 
EFFECTS OF EXCHANGE RATE MOVEMENTS ON EXPORT OF SOME...

Table 7b: Long run effects of exchange rate on the exports of selected agriculture products

\begin{tabular}{|c|c|c|c|c|c|}
\hline Variables & COFFEE & $\overline{\text { SUGAR }}$ & $\begin{array}{c}\text { FRUITS } \\
\text { AND NUTS }\end{array}$ & $\begin{array}{l}\text { VEGETA- } \\
\text { BLES }\end{array}$ & $\overline{\mathrm{COCOA}}$ \\
\hline \multirow{3}{*}{ EXR } & $0.805^{*}$ & $-1.130 * *$ & $0.703^{*}$ & $1.746^{* *}$ & -0.690 \\
\hline & $(0.0640)$ & $(0.030)$ & $(0.046)$ & $(0.020)$ & $(0.3971)$ \\
\hline & 0.071 & 0.0005 & $-0.017 *$ & -0.011 & -0.037 \\
\hline \multirow[t]{2}{*}{ INF } & (0.4698) & $(0.922)$ & $(0.056)$ & $(0.441)$ & $(0.1362)$ \\
\hline & 0.698793* & $-0.126779 *$ & $0.005498^{*}$ & 0.140169* & -0.039158 \\
\hline \multirow[t]{2}{*}{ INT } & $(0.632)$ & $(0.0179)$ & $(0.063)$ & $(0.904)$ & $(0.3949)$ \\
\hline & -0.142756 & 0.025433 & -0.037306 & -0.020281 & 0.070790 \\
\hline \multirow[t]{2}{*}{$\mathrm{TR}$} & $(0.1837)$ & $(0.1486)$ & $(0.723)$ & $(0.475)$ & $(0.1777)$ \\
\hline & 13.890118 & $4.240662 *$ & $2.372366^{*}$ & $12.344696 *$ & $19.235295^{* *}$ \\
\hline TRACT & $(0.1641)$ & $(0.049)$ & $(0.079)$ & $(0.063)$ & $(0.0337)$ \\
\hline $\begin{array}{l}\text { Normality test } \\
\text { (Jack-Bera) }\end{array}$ & $\begin{array}{c}1.027 \\
(0.598)\end{array}$ & $\begin{array}{c}1.855 \\
(0.395)\end{array}$ & $\begin{array}{c}0.250 \\
(0.882)\end{array}$ & $\begin{array}{c}1.294 \\
(0.361)\end{array}$ & $\begin{array}{c}0.333 \\
(0.846)\end{array}$ \\
\hline $\begin{array}{l}\text { Serial correla- } \\
\text { tion test }\end{array}$ & $\begin{array}{c}2.210 \\
(0.740)\end{array}$ & $\begin{array}{l}11.032 \\
(0.601)\end{array}$ & $\begin{array}{c}3.110 \\
(0.128)\end{array}$ & $\begin{array}{c}1.902 \\
(0.444)\end{array}$ & $\begin{array}{l}10.320 \\
(0.881)\end{array}$ \\
\hline $\begin{array}{l}\text { Test for Het- } \\
\text { eroskdasticity }\end{array}$ & $\begin{array}{l}13.032 \\
(0.438) \\
\end{array}$ & $\begin{array}{r}1.983 \\
(0.738) \\
\end{array}$ & $\begin{array}{r}1.840 \\
(0.261) \\
\end{array}$ & $\begin{array}{r}2.691 \\
(0.782) \\
\end{array}$ & $\begin{array}{c}.912 \\
(0.476) \\
\end{array}$ \\
\hline \multicolumn{6}{|c|}{ SOUTH AFRICA } \\
\hline Variables & COFFEE & SUGAR & $\begin{array}{c}\text { FRUITS } \\
\text { AND NUTS } \\
\end{array}$ & $\begin{array}{l}\text { VEGETA- } \\
\text { BLES } \\
\end{array}$ & COCOA \\
\hline \multirow[t]{2}{*}{ EXR } & $\begin{array}{c}-4.567821 \\
(0.244)\end{array}$ & $\begin{array}{c}-0.780849^{* * * *} \\
(0.019)\end{array}$ & $\begin{array}{c}2.102836^{* *} \\
(0.039)\end{array}$ & $\begin{array}{c}-3.71129^{* * *} \\
(0.0159)\end{array}$ & $\begin{array}{c}-4.50854^{* * *} \\
(0.012)\end{array}$ \\
\hline & $\begin{array}{c}0.159704 \\
(0.520)\end{array}$ & $\begin{array}{c}-0.002160 \\
(0.964)\end{array}$ & $\begin{array}{c}0.232728^{* *} \\
(0.040)\end{array}$ & $\begin{array}{c}0.735601 * \\
(0.45)\end{array}$ & $\begin{array}{c}0.288442 \\
(0.231)\end{array}$ \\
\hline INF & -0.390025 & $-0.207345^{* * *}$ & $-0.091681 * *$ & $-0.235539 *$ & -0.221151 \\
\hline \multirow[t]{2}{*}{ INT } & $(0.121)$ & $(0.003)$ & $(0.042)$ & $(0.074)$ & (0.145) \\
\hline & $\begin{array}{c}-0.289197 \\
(0.781)\end{array}$ & $\begin{array}{l}-0.085485 \\
(0.444)\end{array}$ & $\begin{array}{l}1.657102^{* * *} \\
(0.014)\end{array}$ & $\begin{array}{c}-0.202677 \\
(0.704)\end{array}$ & $\begin{array}{c}-0.385367 \\
(0.497)\end{array}$ \\
\hline $\mathrm{TR}$ & -10.542905 & 0.218102 & -0.192587 & $-17.467078^{* * *}$ & $-11.48583^{* * *}$ \\
\hline TRACT & $(0.175)$ & $(0.674)$ & $(0.656)$ & $(0.007)$ & $(0.004)$ \\
\hline $\begin{array}{l}\text { Normality test } \\
\text { (Tack-Bera) }\end{array}$ & $\begin{array}{c}1.289 \\
(0.532)\end{array}$ & $\begin{array}{c}2.774 \\
(0.249)\end{array}$ & $\begin{array}{c}2.298 \\
(0.306)\end{array}$ & $\begin{array}{c}0.095 \\
(0.953)\end{array}$ & $\begin{array}{c}0.757 \\
(0.684)\end{array}$ \\
\hline Serial correlation & 1.111 & 0.932 & 1.437 & 11.342 & 11.832 \\
\hline test & (10.210) & (0.771) & (0.721) & $(0.7832)$ & $(0.842)$ \\
\hline Test for Het- & 1.450 & 2.241 & 4.10 & 2.214 & 12.031 \\
\hline eroskdasticity & $(0.741)$ & $(0.561)$ & $(0.451)$ & $(0.555)$ & $(0.461)$ \\
\hline
\end{tabular}

$*, * *, * * *$ indicate significant at $10 \%, 5 \%, 1 \%$; figures in parentheses are probability values

At the bottom of each panel in the tables efficient and consistent. Hence, the result are various post estimation tests. All the can be relied upon.

tests carried out suggest that the results are

J. Hum. Soc. Sci. Crtv. Arts 2019, 14: 91-112 


\section{CONCLUSION AND POLICY RECOMMEN DATIONS}

The study analyzes the effect of exchange rate movement on the export of five selected agricultural export (cocoa, coffee, sugar, fruits and nuts and sugar), in five emerging economies in Africa (Nigeria, Kenya Egypt, Ghana, South Africa). The ARDL estimation indicates that the effect of exchange rate movement on export of coffee, sugar, vegetables, cocoa and fruits and nuts, differ across countries In some countries exchange rate depreciation is export enhancing while in some, it is export inhibiting. Also the effect differ across products, exchange rate depreciation dwarfs exports of some products while it facilitates export of some others. Given the findings of the study, it can be concluded that exchange rate does not affect agriculture exports varieties the same way and across countries. Hence, policy makers, farmers and academicians should be mindful of the counterproductive nature of exchange rate policy for some farm products.

Base on the findings, the government of (especially in countries where exchange rate depreciation increases export) should embark on policies regarding exchange rate that will increase the export volume. Intervention in the foreign exchange market that will enhance depreciation tends to be a good policy instruments to improve the export volume. The government of these countries should also take into consideration that devaluation of local currency will make import more expensive, so there should be provision for import substitution. Especially for country like Nigeria that depends mostly on import. The government may also focus on other factors that affect export such as inflation rate, interest rate, and export tax. Of importance is the provi- sion of infrastructure for the agricultural industry, in order to promote export. Since it was revealed in the study that availability of tractors which serves as a proxy for infrastructure positively affected export of the five products, for some the five countries. Further, interest rate charged on credit given to farmers should be minimal, so as to encourage borrowing to finance production of agricultural product, which will also increase export. Especially for countries where interest rate affects export negatively.

\section{REFERENCES}

Adekunle, W., Udukwe, I. 2018. The impact of exchange rate dynamics on agricultural output performance in Nigeria. MPRA Paper No 87750. Available at https:/ / mpra.ub.uni-muenchen.de/ id/ eprint/ 87750.

Aktas, A., Kaplan, F., Ozkan, B., Bundfield, R. 2015. Effect of exchange rate uncertainty on agricultural exports: a study of Turkey. Business Management Dynamics 4(8): 18.

Ali, S. 2017. Exchange rate effects on agricultural exports: firm-level evidence from Pakistan. Gldbal, productivity and techndogy re search Paper 2017/ 09. Available at https:/ / www.nottingham.ac.uk/gep/ documents/ papers/ 2017/ 2017-09.pdf.

Arcand, J.L., Guillaumont, P., Guillaumont, S.J., 2008. D eforestation and the Real Exchange Rate. Joumal of DedopmentEconm ics 86: 242-262.

Chamunorwa, W., Choga, I. 2015. Exchange Rate Volatility and Export Performance in South Africa. Asian Ecomomic and Finanial Review5(10).

Chi, J., Cheng, S. 2016. D o Exchange Rate 
EFFECTS OF EXCHANGE RATE MOVEMENTS ON EXPORT OF SOME...

Volatility and Income Affect Australia's Marshall, A. 1923. Money, Credit and Com Maritime Export Flows to Asia. Transport mece London, Macmillan.

Pdigy47: 13-21.

FA0STAT 2018. Statistical Podkebook.

Najia, S., Irfan S., 2012. Exchange Rate Food and Agriculture Organization of the United Nations.

Volatility and its Effect on Pakistan's Export Volume. Advances in Management \& Applied Econamics 2(4): 109-124.

Genc, E., Kibritci, O. 2014. The Effects of Exchange Rates on Exports and Imports of Emerging Countries. Eurqpenn Saientific Jaumal 10(13): 1857 - 7881.

Hsu, W., Lu, Y., Zhou, Y. $2014 . \quad$ Exchange rates and export structure. 1-33. Research Collection School of Economics. Available at https:/ / ink.library.smu.edu.sg/ soe research/ 1721.

IMF 2018. Sub-Saharan Africa Capital flows and the future work: Background Paper-online annexes. Regjonal EcommicOutlook, IMF, Washington DC.

Innocent, S. 2014. The Impact of Exchange Rate Expectations and Interest Rate Differentials on Trade in South Africa: An Econometric Analysis. Medteranem Jaumal of Social Saienes 5(2) ISSN 2039-9340.

Lemer, A. 1944. The Econmics of Contrd Priniples and Wefare Economics London, Macmillan.

Li, H., Ma, H., Xu, Y. 2015. How do exchange rate movements affect Chinese exports? A firm-level investigation. Joumal of Intemational Econamics97(1).

Malik, A., Hassan, R., Shah, S., change rates on exports: (a case of developing economy). Jaumal of Humanities and So dal Saiences 6(3): 112-122.

Obayelu, E., Salau, A. Agricultural Response to Prices and Exchange Rate in Nigeria: Application of $\mathrm{Co}$-integration and Vector Error Correction Model (VECM). De partment of Agiaultural Econmics and Fam Management, Univesity of Agialture Abeokuta (UNAAB), Ogm StateNigria, 1(2): 73-81.

Obinwata, I., Owuru, J., Farayibi, A. 2016. Exchange rate trends and export performance in Nigeria. A descriptive approach. MPRA Paper Non 75526.

Ramesh, C., Paudel, P., Burke, J. 2015. Exchange Rate Policy and Export Performance in a Landlocked D eveloping Country: The case of Nepal. Jaumal of AsianEconmics 38: 55-63.

Reboredo, J.C., Ugando, M. (2014), US Dollar Exchange Rate and Food Price Dependence: Implications for Portfolio Risk Management. Noth American Joumal of Eœ nomics and Finance (2014), http:/ / dx.ddi.org 10.1016/j.naje.2014.08.005.

Ronald A.B., Fred, J., Ruppel, D. Bessler, A. 1995. U.S. Corn Exports: the Role of the Exchange Rate. Agiaultural Eø mamics 13: 75-88.

Sanderson, L. 2009. Exchange Rates and Export Performance: Evidence from MicroD ata ReserveBank of NewZealand Bullein, 72 (2). 
Shotar, M., El-Mefleh, A. 2009. Economic Exposure to Exchange Rates in Jordan Companies: Theoretical Framework and Literature Review. Jaumal of Applied Econo merics and Intemational Dedopment 9(1).

Smith, M. Impact of the Exchange Rate on Export. ReserveBank of NewZealand Bullein 67(1).

Tamar, R. 2016. Impact of the 2015 U.S. Dollar Rise on Export Prices and on the Agricultural Industry. Beyond the Numbers: Gldbal Econamy5(18).
Wanhui J. 2014. The Effect of RMB Exchange Rate Volatility on Import and Export Trade in China. Intemational Jaumal of Aca demicReserchin Business and Social Saiences 4(1). Wondemu, K., Potts, D. 2016. The Impact of the Real Exchange Rate Changes on Export Performance in Tanzania and Ethiopia. Working Paper Series No240, African Dededpment Bank, Abidjan, Côtedivirire

World Bank 2019. Wodd IntegratedTradeSo lutions The World Bank Group.

(Manuscipt recived 11thFednuary, 2019; accepted: 22ndNowember, 2019) 